\title{
PENGARUH LEDAKAN POPULASI IKAN SAPU-SAPU (PTERYGOPLICHTHYS SPP) TERHADAP PRODUKSI HASIL TANGKAPAN JARING INSANG DI PERAIRAN DANAU SIDENRENG
}

\section{Effect of Sailfin Catfish (Pterygoplichthys Spp) Population Explosions on Production of Gill Net Catches at Lake Sidenreng Waters}

\author{
Oleh: \\ Hasrianti ${ }^{1}$, Surianti ${ }^{1 *}$, Muhammad Rais Rahmat Razak $^{2}$ \\ ${ }^{1}$ Fakultas Sains dan Teknologi, Universitas Muhammadiyah \\ Sidenreng Rappang, Indonesia \\ ${ }^{2}$ Fakultas Ilmu Sosial dan Ilmu Pemerintahan,Universitas \\ Muhammadiyah Sidenreng Rappang, Indonesia \\ *Korespondensi penulis: anthiafnan@outlook.com
}

\begin{abstract}
ABSTRAK
Salah satu jenis ikan yang termasuk dalam golongan invasive species adalah ikan sapu-sapu. Terjadinya ledakan populasi ikan sapu-sapu di perairan Danau Sidenreng memberikan dampak terhadap keberlanjutan biodiversitas perairan juga memberikan dampak terhadap produksi hasil tangkapan nelayan. Penelitian ini dilakukan dengan tujuan untuk mengetahui pengaruh ledakan populasi ikan sapu-sapu terhadap volume hasil tangkapan nelayan jaring insang. Penelitian ini dilaksanakan pada bulan Juni hingga Agustus 2020 di Desa Teteaji dan Kelurahan Wette'e, Kab. Sidenreng Rappang. Berdasarkan perbandingan jumlah hasil tangkapan (jumlah ekor) diperoleh persentase jumlah hasil tangkapan ikan target per trip penangkapan yaitu $46,19 \%$ dan untuk tangkapan buangan (ikan sapu-sapu) 53,81\%. Berdasarkan hasil analisis uji Mann-Whitney didapatkan nilai Asympe sig (2 tailed) sebesar 0.000 yang artinya $p$ value $<0,05$ yang menunjukkan bahwa h0 ditolak. Hal ini menandakan terdapat perbedaan volume hasil tangkapan nelayan sebelum adanya ledakan populasi ikan sapu-sapu dan saat terjadi ledakan populasi ikan sapu-sapu di perairan Danau Sidenreng.

Kata kunci: ikan sapu-sapu, invasive spesies, jaring insang, ledakan populasi

\section{ABSTRACT}

One type of fish that is included in the class of Invasive Species is the Sailfin Catfish. The occurrence of Sailfin Catfish population explosion in the waters of Lake Sidenreng had an impact on the sustainability of aquatic biodiversity as well as an impact on the production of fishermen's catch. This research was conducted to determine the effect of sailfin catfish population explosion on catch volume of gill net fishermen. This research was conducted from June to August 2020 in Teteaji Village and Wette'e Village, Kab. Sidenreng Rappang. Based on the comparison of the number of catches (number of tails), the percentage of the number of target fish catches per trips is $46.19 \%$ and $53.81 \%$ for the waste catch (sailfin catfish). Meanwhile, based on the results of the Mann Whitney test analysis, the Asympe Sig (2 tailed) value was 0.000, which means that the $p$ value $<0.05$, which indicates that ho is rejected. This indicates that there was a difference in the volume of the fishermen's catch before the broomfish population explosion and when the broomfish population explosion occurred in Sidenreng Lake waters.
\end{abstract}

Key words: gill net, invasive spesies, population explosions, sailfin catfish (Pterygoplichthys spp) 


\section{PENDAHULUAN}

Perairan Danau Sidenreng merupakan salah satu ekosistem perairan tawar yang memiliki potensi yang besar di Sulawesi Selatan dengan luas $\pm 4.753,30$ ha yang berfungsi sebagai penghasil ikan yang dimanfaatkan oleh nelayan-nelayan yang bermukim di sekitar Danau Sidenreng guna untuk memenuhi kebutuhan protein hewani dan meningkatkan pendapatan rumah tangga nelayan.

Pada mulanya Danau Sidenreng, Danau Tempe, dan Danau Buaya merupakan satu kesatuan yang disebut sistem Danau Tempe, namun ketiganya terpisah dan masing-masing mempunyai nama tersendiri yang disebabkan karena adanya sedimentasi yang berlangsung secara terus menerus dan terjadi pendangkalan. Namun saat ini pada musim hujan ketiga danau tersebut bersatu dan pada musim kemarau ketiga danau tersebut kembali terpisah. Ada berbagai jenis ikan yang tertangkap di danau antara lain ikan sepat siam, nilem, betok, sidat, gabus, lele, nila, tawes, mas, betutu, mujair, belut sawah dan udang tawar (KLHRI, 2014).

Berbagai jenis ikan di Danau Sidenreng mulai mengalami kepunahan akibat kegiatan penangkapan dan kegiatan sehari-hari masyarakat sekitar danau. Beberapa kegiatan yang merusak adalah pemakaian alat tangkap yang tidak selektif, electrical fishing, penggunaan racun dan bahan peledak, pembuangan limbah rumah tangga dan pertanian, pertumbuhan gulma, serta pendangkalan (Andy Omar, 2010).

Salah satu hal yang juga diduga mempengaruhi keragaman spesies ikan yang terdapat di Danau Sidenreng adalah kehadiran spesies invasif yaitu ikan sapu-sapu (Pterygoplichthys spp). Keberadaan spesies ikan sapu-sapu yang mengalami ledakan populasi (peningkatan jumlah spesies dari tahun ke tahun) mengakibatkan ikan tersebut menjadi ancaman tersendiri bagi populasi spesies ikan-ikan lokal yang ada. Thalathiah \& Palanisamy (2004) menyatakan bahwa jenis ikan yang terdampak dengan kehadiran sapu-sapu adalah ikan-ikan dari famili Cyprinidae seperti ikan mas.

Makanan ikan sapu-sapu adalah alga, ganggang bentik, detritus, cacing dan beberapa jenis larva serangga (Ozedilek 2007) dan berdasarkan nilai panjang relatif usus ikan sapu-sapu dikategorikan sebagai ikan herbivora (Dewi 2020) sementara itu Chaicana \& Jongphadungkiet (2012) menyatakan bahwa ikan sapu-sapu juga memangsa ikan-ikan kecil dan telur ikan.

Terdapat 2 jenis alat tangkap yang dioperasikan nelayan di danau Sidenreng yakni alat tangkap jaring insang (gill net) dan bubu (trap). Jaring insang merupakan alat tangkap yang paling dominan dioperasikan oleh nelayan-nelayan danau Sidenreng. Alat tangkap jaring insang adalah alat tangkap yang digunakan dalam aktivitas penangkapan komersial dan juga dapat dimanfaatkan dalam pengkajian populasi ikan di suatu perairan (Nedreaas et al, 1996).

Terjadinya penurunan hasil tangkapan nelayan di Danau Sidenreng yang dibuktikan dengan volume hasil tangkapan sebelum adanya ledakan populasi ikan sapu-sapu yang bisa mencapai 100 $\mathrm{kg} /$ trip dan saat ini mengalami penurunan volume hasil tangkapan yang diduga disebabkan karena terjadinya ledakan populasi ikan sapu-sapu yang juga berdampak terhadap efektivitas dan efisiensi penangkapan ikan.

Penelitian ini dilakukan untuk mengetahui komposisi jenis hasil tangkapan di Danau Sidenreng dan menganalisis perbandingan produksi hasil tangkapan ikan sebelum adanya ikan sapu-sapu dan setelah terjadinya ledakan populasi ikan sapu-sapu.

\section{METODE PENELITIAN}

Penelitian ini dilaksanakan pada bulan Juni sampai Agustus 2020 di Danau Sidenreng yaitu di Desa Teteaji, Kecamatan Tellu Limpoe dan di Kelurahan Wette'e, Kecamatan Panca Lautang, Kabupaten Sidenreng Rappang. Data hasil tangkapan yang dikumpulkan berupa data hasil tangkapan sebelum terjadinya ledakan populasi ikan sapu-sapu dan data hasil tangkapan saat terjadi ledakan 
populasi ikan sapu-sapu di Danau Sidenreng. Pengambilan data dilakukan menggunakan metode wawancara, angket dan observasi. Untuk data rata-rata perbandingan volume hasil tangkapan sebelum adanya ledakan populasi ikan sapu-sapu dan saat sekarang (saat terjadi ledakan populasi ikan sapu-sapu) menggunakan metode wawancara dengan 33 responden nelayan, sedangkan untuk data perbandingan jumlah ekor hasil tangkapan utama dan ikan invasif (ikan sapu-sapu) dilakukan dengan pengambilan data secara langsung pada 9 nelayan jaring insang di Danau Sidenreng. Berikut peta lokasi penelitian disajikan pada Gambar 1 di bawah ini.

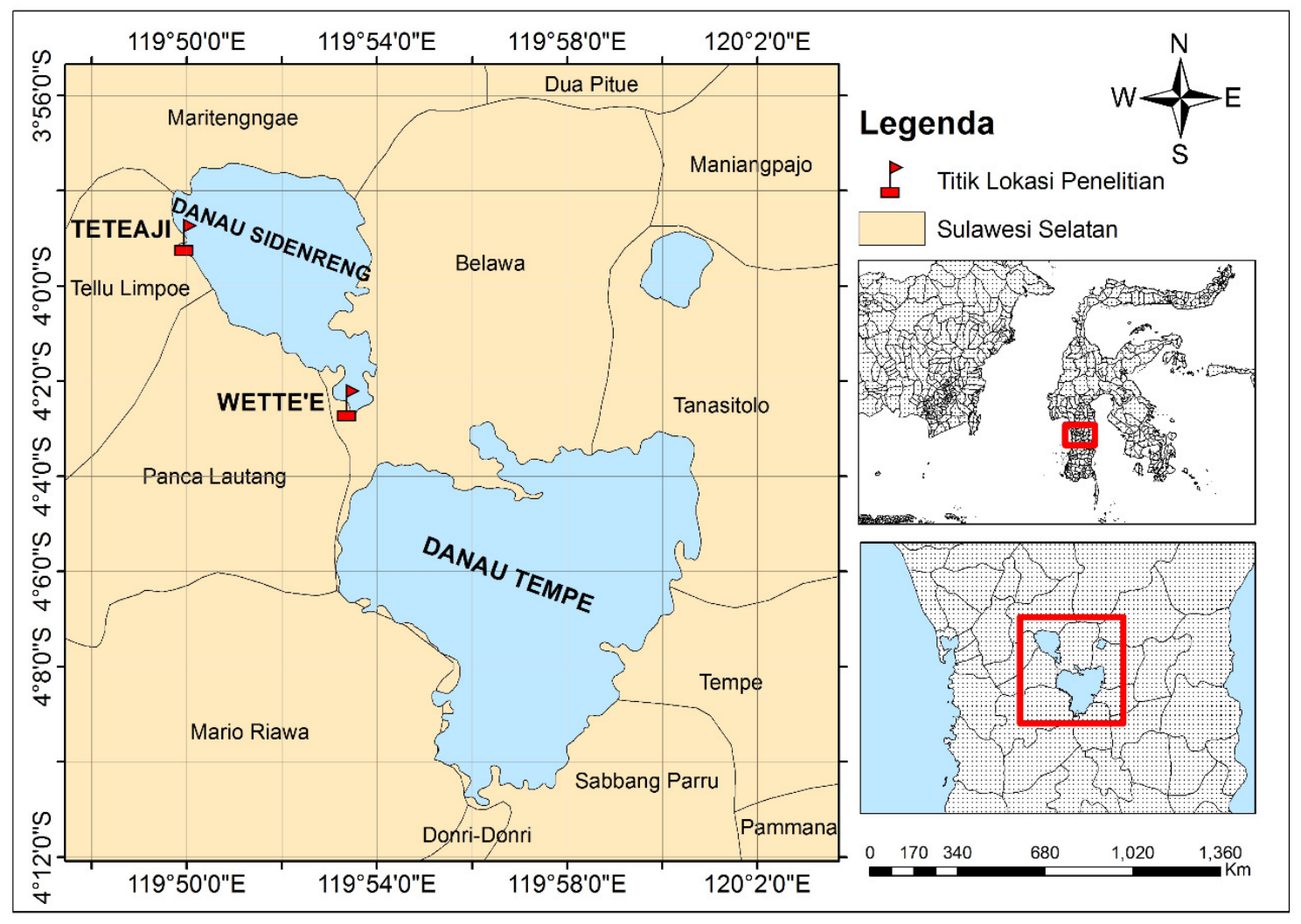

Gambar 1 Peta lokasi penelitian

Analisis data dilakukan untuk mengetahui pengaruh ledakan populasi ikan sapu-sapu terhadap volume hasil tangkapan nelayan Danau Sidenreng sebelum terjadinya dan setelah terjadinya ledakan populasi ikan sapu-sapu, dimana perhitungannya menggunakan spps uji Mann-Whitney Test

Hipotesis sebagai berikut:

- H0 : Tidak ada pengaruh ledakan populasi ikan sapu-sapu terhadap volume hasil tangkapan nelayan Danau Sidenreng sebelum adanya ledakan populasi dan saat terjadinya ledakan populasi ikan sapu-sapu.

- H1 : ledakan populasi ikan sapu-sapu memberikan pengaruh terhadap volume hasil tangkapan nelayan Danau Sidenreng sebelum adanya ledakan populasi dan saat terjadinya ledakan populasi ikan sapu-sapu.

Dengan penentuaan keputusan : Jika, $\mathrm{t}$ hitung $<\mathrm{t}$ tabel berarti tidak terdapat pengaruh ledakan populasi ikan sapu-sapu terhadap volume hasil tangkapan sebelum adanya ledakan populasi dan saat terjadi ledakan populasi ikan sapu-sapu, sedangkan $t$ hitung $>t$ tabel berarti terdapat pengaruh ledakan populasi ikan sapu-sapu terhadap volume hasil tangkapan sebelum adanya ledakan populasi dan saat terjadi ledakan populasi ikan sapu-sapu. 


\section{HASIL DAN PEMBAHASAN}

\section{Komposisi Jenis Hasil Tangkapan}

Hasil tangkapan utama (target species) dari alat tangkap yang dioperasikan nelayan di Danau Sidenreng yaitu ikan nila dan ikan tawes dengan tangkapan sampingannya yaitu ikan gabus, ikan patin, ikan mas dan ikan betutu dll. Persentase antara hasil tangkapan target \& tangkapan sampingan dengan hasil tangkapan buangan sailfin catfish (invasive species) berdasarkan jumlah (ekor) tangkapan yaitu 53,81\% untuk tangkapan spesies target \& bycatch dan 46,19\% untuk tangkapan buangan. Persentase jumlah (ekor) hasil tangkapan disajikan pada Tabel 1 dan perbandingan hasil tangkapan spesies target \& bycatch dengan hasil tangkapan ikan sapu-sapu sailfin catfish (invasive species) disajikan pada tabel di bawah ini.

Tabel 1 Persentase jumlah ikan hasil tangkapan nelayan jaring insang

\begin{tabular}{cccc}
\hline $\begin{array}{c}\text { Target Spesies \& } \\
\text { Bycatch }\end{array}$ & $\begin{array}{c}\text { Invasive Species } \\
\text { (Sailfin Catfish) }\end{array}$ & $\begin{array}{c}\text { Persentase Target } \\
\text { Spesies \& Bycatch }\end{array}$ & $\begin{array}{c}\text { Persentase Invasive } \\
\text { Species (Sailfin Catfish) }\end{array}$ \\
\hline 20 & 9 & $1.48 \%$ & $0.57 \%$ \\
96 & 189 & $7.11 \%$ & $12.02 \%$ \\
39 & 22 & $2.89 \%$ & $1.40 \%$ \\
356 & 89 & $26.37 \%$ & $5.66 \%$ \\
137 & 79 & $10.15 \%$ & $5.02 \%$ \\
77 & 96 & $5.70 \%$ & $6.10 \%$ \\
45 & 67 & $3.33 \%$ & $4.26 \%$ \\
420 & 843 & $31.11 \%$ & $53.59 \%$ \\
160 & 179 & $11.85 \%$ & $11.38 \%$ \\
\hline
\end{tabular}

\section{Perbandingan Hasil Tangkapan}

Target Spesies \& Bycatch $\square$ Invasive Species (Sailfin Catfish)

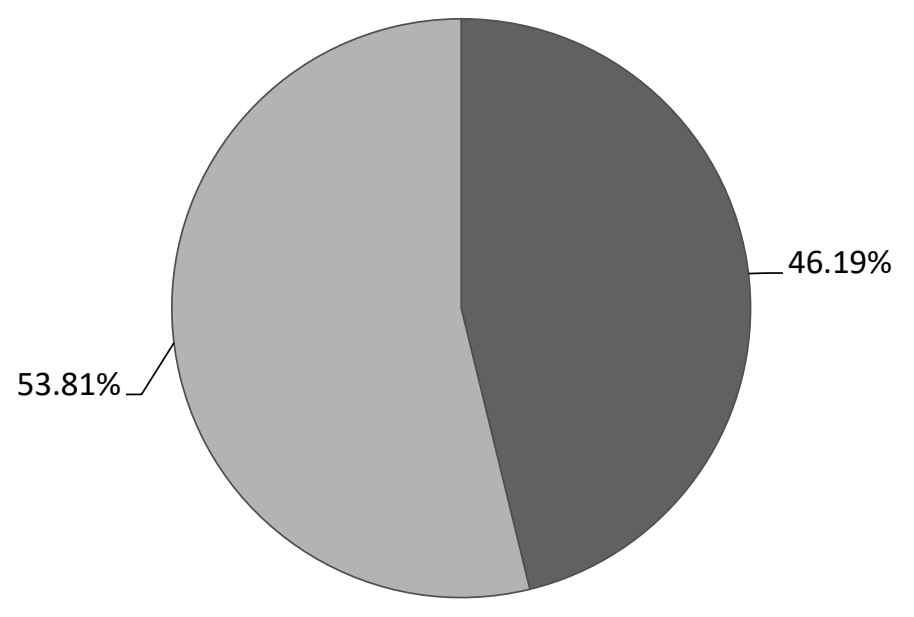

Gambar 2 Proporsi hasil tangkapan ikan dari sembilan kapal nelayan jaring insang dalam 1 kali trip penangkapan 
Diagram proporsi hasil tangkapan (Gambar 2) menunjukkan bahwa hasil tangkapan buangan memiliki persentasi yang lebih besar dibandingkan dengan tangkapan target, dimana tangkapan target 46.19\% sedangkan tangkapan buangan (ikan sapu-sapu) mencapai 53.81\%. hal tersebut membuktikan bahwa keberadaan ikan sapu-sapu di perairan Danau Sidenreng telah menjadi ancaman bagi populasi spesies ikan lokal yang ada. Hal tersebut disebabkan karena ikan sapu-sapu dapat memiliki kemampuan adaptasi yang tinggi, sehingga memungkinkan untuk dapat menjadi hama di suatu perairan (Wahyudewantoro, 2018).

Persentasi proporsi hasil tangkapan utama jaring insang yang menurun dan tangkapan buangan (ikan sapu-sapu) yang mengalami peningkatan di duga dipicu oleh terjadinya persaingan dan kebiasaan makan ikan sapu-sapu yang memakan telur ikan. Knight (2010) menginformasikan bahwa "Dampak ekologi yang ditimbukan dari ikan sapu-sapu (Pterygoplichthys sp) ialah terganggunya rantai makanan akuatik akibat pemanfaatan (komsumsi) berlebihan pada jenis alga bentik dan detritus di perairan serta penurunan jumlah spesies asli (ikan lokal perairan) akibat persaingan dan kerusakan telur".

\section{Komposisi Jenis-Jenis Ikan yang Tertangkap}

Jenis ikan hasil tangkapan jaring insang di Danau Sidenreng tersaji pada Gambar 3. Jenis ikan yang sering tertangkap pada jaring terdiri dari 6 jenis. Persentase jumlah (ekor) ikan yang tertangkap berdasarkan Jenis yang paling dominan dan paling banyak tertangkap (target utama) yaitu ikan tawes (Barbonymus goniono Bleeker, 1850) sebanyak 67\%, ikan nila (Oreochromis niloticus) 19\% dan ikan gabus (Channa striata) 6\%, selain itu beberapa jenis yang juga kadang tertangkap pada jaring yaitu ikan bungo (Glossogobius sp) sebanyak 4\%, ikan mas (Cyprinus carpio) sebanyak 2\%, ikan patin (Pangasius sp) sebanyak 1\% dan ikan betutu (Oxyeleotris marmorata) juga sebanyak 1\%.

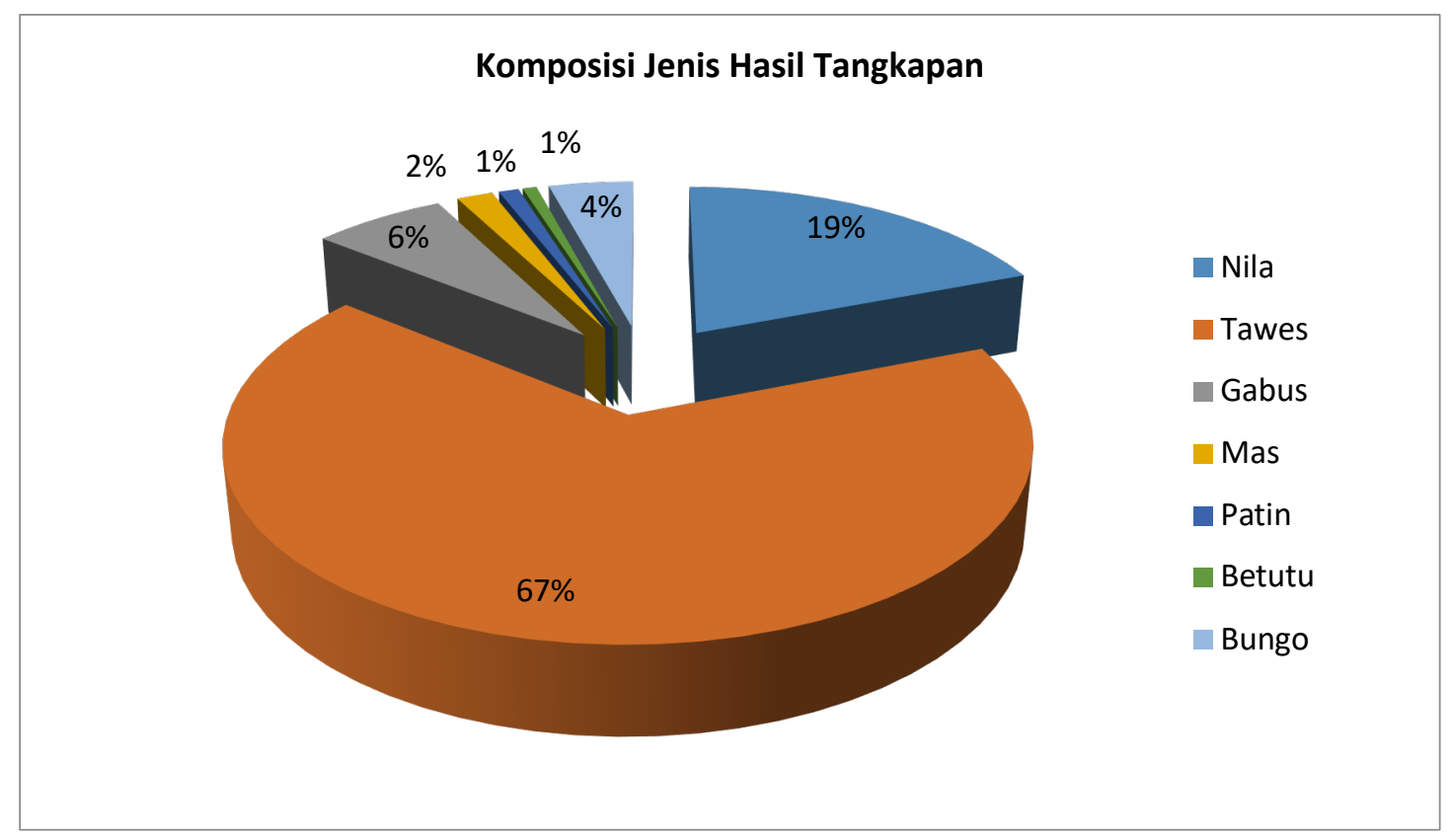

Gambar 3 Persentase komposisi jenis hasil tangkapan ikan

Jenis ikan hasil tangkapan jaring insang di Danau Sidenreng tersaji pada Gambar 3. Jenis ikan yang sering tertangkap pada jaring terdiri dari 6 jenis, yaitu ikan tawes (Barbonymus goniono Bleeker, 1850), ikan nila (Oreochromis niloticus) dan ikan gabus (Channa striata), ikan patin (Pangasius sp), ikan betutu (Oxyeleotris marmorata), ikan mas (Cyprinus carpio), dan ikan bungo (Glossogobius sp).

Berdasarkan diagram komposisi jenis ikan yang tertangkap pada jaring insang menunjukkan bahwa keberadaan ikan sapu-sapu (Pterygoplichthys sp) memberikan dampak terhadap keberagaman 
ikan hasil tangkapan nelayan. Kondisi tersebut sama dengan yang terjadi di Sungai Ciliwung yang dilaporkan Hadiaty (2011) populasi ikan sapu sapu yang mendominasi perairan sungai sehingga beberapa spesies ikan yang dahulu mudah ditemukan diantaranya benteur (Barbodes binotatus), tawes tawesan (Barbonymus Spp.) saat ini sudah sulit diperoleh.

\section{Perbandingan Volume Hasil Tangkapan}

Berdasarkan output hasil analisis mann white test didapatkan nilai Asympe sig (2 tailed) sebesar 0.000 yang artinya $\mathrm{p}$ value $<0,05$ maka ho ditolak dan h1 diterima. Hal ini menandakan terdapat perbedaan volume hasil tangkapan nelayan per trip sebelum adanya ledakan populasi ikan sapu-sapu dan saat terjadi ledakan populasi ikan sapu-sapu di Danau Sidenreng. Nilai mean pada kondisi sebelum adanya ikan sapu-sapu sebesar 45.55 sedangkan setelah adanya ledakan populasi ikan sapu-sapu nilai mean sebesar 21.45, hal tersebut menunjukkan bahwa produksi ikan hasil tangkapan nelayan jaring insang sebelum adanya ikan sapu-sapu relatif lebih tinggi dibandingkan dengan produksi hasil tangkapan setelah adanya ikan sapu-sapu di perairan Danau Sidenreng. Dapat disimpulkan bahwa setelah adanya spesies ikan sapu-sapu produksi hasil tangkapan nelayan jaring insang di Danau Sidenreng mengalami penurunan produksi hasil tangkapan. Penurunan hasil tangkapan dan berkurangnya jenis spesies tangkapan nelayan membuktikan bahwa keberadaan ikan sapu-sapu berpengaruh terhadap keberagaman dan populasi ikan lokal yang ada di perairan Danau Sidenreng.

Keberadaan ikan sapu-sapu yang tergolong ikan invasif dapat mengakibatkan kerusakan bahkan lenyapnya komunitas ikan lokal yang ada diperairan, sebagai contoh kasus seperti ikan mujair yang diintroduksi ke Indonesia pada tahun 1939. Kemudian 1951 diintroduksi ke Danau di Sulawesi dan menjadi invasif yang mengakibatkan kepunahan ikan lokal yaitu ikan moncong bebek (Adrianichthys kruyti dan Popta's buntingi (Xenopoecilus poptae) yang keduanya merupakan jenis endemik dari Danau Poso (Wahyudewantoro \& Rachmatika 2016).

\section{KESIMPULAN DAN SARAN}

Ledakan populasi ikan sapu-sapu di Danau Sidenreng memberikan pengaruh terhadap volume hasil tangkapan. Hasil tangkapan nelayan jaring insang dalam 9 kali trip penangkapan berdasarkan jumlah (ekor) diperoleh $46,19 \%$ untuk tangkapan spesies target \& bycatch dan 53,81\% untuk tangkapan buangan (ikan sapu-sapu).

\section{UCAPAN TERIMA KASIH}

Tulisan ini merupakan bagian dari hasil kegiatan penelitian dosen pemula yang didanai oleh Kemenristek-BRIN tahun anggaran 2020, penulis mengucapkan terima kasih kepada Menteri Riset dan Teknologi/Kepala Badan Riset dan Inovasi Nasional (Menristek/Kepala BRIN), tim peneliti, dan pembantu lapangan yang telah membantu selama kegiatan pengambilan data di lapangan.

\section{DAFTAR PUSTAKA}

Andy Omar, S. Bin. 2010. Aspek reproduksi ikan nilem Osteochilus vittatus (Valenciennes, 1842) di Danau Sidenreng, Sulawesi Selatan. Jurnal Ikhtiologi Indonesia, 10 (2) : $111-122$

Chaicana R \& S. Jongphadungkiet. 2012. Assesment of the invasive catfish Pterygoplichthys pardalis (Castelneu, 1855) in Thailand: Ecological impacts and biological control alternatives. Tropical Zoology 25(4): 173-182.

Dewi, M., Suwarni. dan Andy Omar, S.B., 2020. Kebiasaan Makanan Ikan Sapu-sapu (Pterygoplichthys multiradiatus Hancock, 1828) di Perairan Danau Sidenreng, Kabupaten Sidenreng Rappang, 
Sulawesi Selatan. Prosiding Simposium Nasional VII Kelautan dan Perikanan 2020 Fakultas Ilmu Kelautan dan Perikanan, Universitas Hasanuddin, Makassar, 5 Juni 2020

Hadiaty RK. 2011. Diversitas dan hilangnya jenisjenis ikan di Sungai Ciliwung dan Sungai Cisadane. Berita Biologi. 10(4):491-504.

Kementerian Lingkungan Hidup Republik Indonesia. 2014. Gerakan Penyelamatan Danau (GERMADAN) Tempe.

Knight J.D.M. (2010). Invasive ornamental fish: a potential threat to aquatic biodiversity in peninsular India. Journal of Threatened Taxa, 2(2): 700-704.

Nedreaas, K.H., Soldal, A.V. and Bjordal, A., 1996. Performance and biological implications of a multigear fishery for Greenland halibut (Reinhardtius hippoglossoides). Journal of Northwest Atlantic Fishery Science, 19, pp.59-72.

Ozedilek S.Y. 2007. Possible therats for Middle East inland water; an exotic species, Pterygoplichthys disjuntivus (Weber 1991) in Asi river, Turkey (Pisces: Loricariidae). Journal of Fisheries and Aquatic Science, 24: 303-306.

Thalathiah S., \& V. Palanisamy. 2004. Country paper: Malaysia. The way forward: building capacity to combat impacts of aquatic invasive alien species and associated transboundary pathogens in ASEAN countries. In final report of a workshop hosted by the Department of Fisheries, Goverment of Malaysia (2004) 12-16th July 2004. The Network of Aquaculture Centers of AsiaPasific (NACA) March 2005.

Wahyu dewantoro, G. 2018. Sapu-sapu (Pterygoplichthys Spp.), Ikan Pembersih Kaca yang Bersifat Invasif Di Indonesia. Warta Iktiologi Vol 2(2).

Wahyudewantoro, G dan Rachmatika, I. 2016. Jenis Ikan Introduksi dan Invasif Asing di Indonesia. LIPI Press. Jakarta. 192p. 